\author{
Józef RÓŻański, DAMian NOWAK, JAROSŁaW SOCHACKI, KONRAD KRAsoń
}

Zespót ds. Ochrony Przyrody

Magurski Park Narodowy

Krempna 59, 38-232 Krempna

Email: jrozanski@magurskipn.pl

jozekr1@poczta.onet.pl

\title{
MAGURSKI PARK NARODOWY - ZNACZENIE DLA NAUKI
}

\section{WSTEP}

Koncepcja utworzenia parku narodowego $\mathrm{w}$ Beskidzie Niskim po raz pierwszy przedstawiona została przez Komitet Ochrony Przyrody i Jej Zasobów Polskiej Akademii Nauk w 1975 r. Projekt ten obejmował propozycję prawnej ochrony masywu Magury Watkowskiej, Magury Małastowskiej oraz pasma Dziamery i Ostrej Góry (SZAFRAŃSKI 2009). W 1981 r. dr Stefan Michalik zaproponował utworzenie sieci obszarów chronionych w Karpatach, $z$ uwzględnieniem 9 tys. ha w masywie Magury Watkowskiej, a 1983 r., Komitet Ochrony Przyrody Polskiego Towarzystwa Leśnego wystapił $z$ propozycja utworzenia parku narodowego na obszarach Magury Watkowskiej i masywu Mareszki. W 1991 r. prof. dr hab. Stefan Michalik przeprowadził kompleksowa waloryzacje przyrodnicza, uzasadniająca konieczność utworzenia Magurskiego Parku Narodowego. Oprócz wymienianych wcześniej terenów, w skład Parku wchodzić miały obszary pasm Uherca, Feszówki, Działu, Nad Tysowym, Baranie oraz enklawy nieleśne $\mathrm{w}$ dolinach Ciechani, Żydowskiego, Huty Polańskiej i Świerzowej Ruskiej (SZAFRAŃSKI 2009). Dnia 30 lipca 1991 r. wojewoda krośnieński zwrócił się do ministra Ochrony Środowiska, Zasobów Naturalnych i Leśnictwa $z$ wnioskiem o utworzenie Magurskiego Parku Narodowego. Zgodnie $z$ rozporzadzeniem Rady Ministrów z dnia 24 listopada 1994 r., Park rozpoczał funkcjonowanie 1 stycznia 1995 r. (SZAFRAÑSKI 2009).

Obszar Parku rozciaga się na $194,39 \mathrm{~km}^{2}$, zaś jego otulina na dodatko-

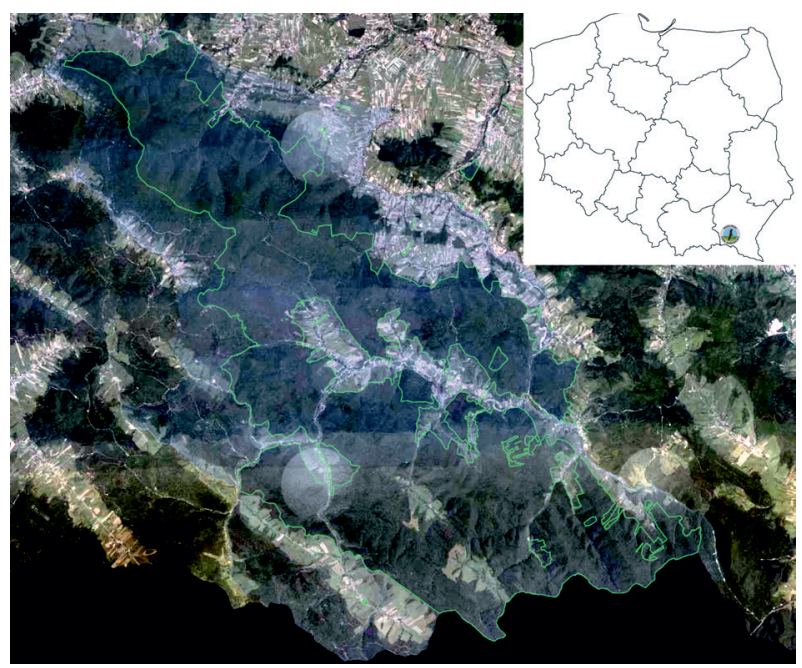

Ryc. 1. Mapa Magurskiego Parku Narodowego wraz $z$ otulina Parku.

błękitne pole - teren MPN z uwzględnieniem obszaru otuliny, zielona linia - granica MPN. W prawym górnym rogu, lokalizacja MPN na mapie Polski (Geoserwis GDOŚ 2019, zmieniona).

wej powierzchni 229,69 $\mathrm{km}^{2}$ (Ryc. 1). Przesłanki do założenia parku narodowego w centralnej części Beskidu Niskiego wynikały $z$ licznych walorów przyrodniczych tego rejo$\mathrm{nu}$, a przede wszystkim $\mathrm{z}$ potrzeby objęcia najwyższa forma ochrony typowego krajobrazu (Ryc. 2) najniższej części polskich Karpat (CZADERna 2009). Kolejnym kluczowym powodem było położenie Parku na skrzyżowaniach głównych korytarzy ekologicznych „północ-południe” oraz „wschód-zachód” (CZADERNA 2009). Warto podkreślić, że teren, na którym obecnie znajduje się Park,
\end{abstract}




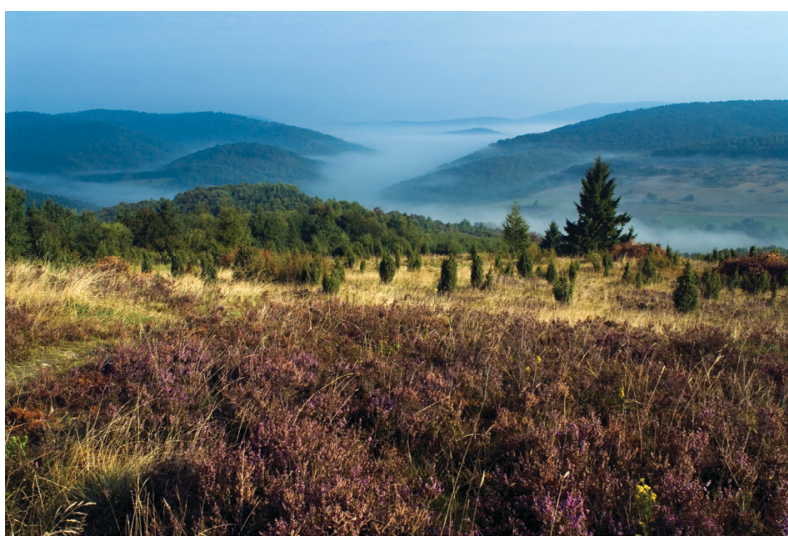

Ryc. 2. Krajobraz charakterystyczny dla MPN. Fot. D. Nowak.

jest obszarem przejściowym między Karpatami Wschodnimi a Karpatami Zachodnimi. Walory przyrodnicze Magurskiego Parku Narodowego widoczne sa zarówno w przyrodzie nieożywionej, jak i ożywionej. $Z$ punktu widzenia geologicznego, dominującym zespołem jest flisz karpacki $z$ podłożem płaszczowiny magurskiej, a w niewielkim stopniu też dukielskiej $i$ śląskiej. Najbardziej charakterystycznymi krajobrazowo punktami sa Wodospad Magurski i Diabli Kamień (MichalıK 1995). W pokrywie glebowej Magurskiego Parku Narodowego dominuja gleby brunatne, występujace na $85-90 \%$ powierzchni Parku. Przeważaja wśród nich gleby brunatne mezotroficzne i eutroficzne (wyługowane i oglejone). Gleby kwaśne stanowia 25\% gleb brunatnych. Pozostałe utwory glebowe, zajmujace $10-15 \%$, to głównie gleby glejowe i mady. Na obszarze tym spotyka się także gleby torfowe (SKIBA i DREWNIK 2000).

Bogactwo flory jest ściśle zwiazane ze zbiorowiskami roślinnymi. Naturalne zbiorowiska, na które składa się 57 zespołów roślinnych lub jednostek równorzędnych, stanowią zdecydowaną większość wszystkich siedlisk. Pomimo że 95\% powierzchni Parku stanowia zbiorowiska leśne, większa różnorodnościa odznaczaja się zbiorowiska nieleśne. Spośród 16 naturalnych zespołów leśnych i zbiorowisk w randze zespołów, najczęściej spotykanym jest buczyna karpacka, która składa się na charakter krajobrazowy leśnej części MPN. Ciekawostka jest obecność rzadkich w Karpatach jaworzyn: karpackiej, górskiej z języcznikiem zwyczajnym Phyllitis scolopendrium i miesiacznicowej (CZADERna 2009, Michalik 2009). Cennym podzespołem buczyny karpackiej jest wschodniokarpacki podzespół $z$ kostrzewa górska Festuca drymeja oraz podzespoły wilgotne $z$ czosnkiem niedźwiedzim Allium ursinum i miesiącznica trwała Lunaria rediviva. Spotyka się także grą subkontynentalny. W siedliskach wilgotniejszych można spotkać nadrzeczną olszynę górska, bagienną olszynę górska oraz łęg jesionowy i typowy dla siedlisk niżowych, ols bagienny. Lasy szpilkowe i mieszane, będące druga grupa zbiorowisk, maja charakter porolny, wynikający $z$ tendencji zmian niegdyś użytkowanych rolniczo gruntów w kierunku zbiorowisk leśnych. Do zbiorowisk zaroślowych należa zarośla $z$ września pobrzeżna Myricaria germanica i wikliny nadrzeczne. Na śródleśnych młakach występuja zarośla bagienne $z$ wierzba uszata Salix aurita. W skład obszarów nieleśnych, zajmujaccych niespełna 5\% powierzchni Parku, wchodza 34 zespoły i zbiorowiska w randze zespołów. Wyróżnić można tu przede wszystkich zbiorowiska lakkowe i szuwarowe. Najczęściej występuja w tym rejonie łąki i pastwiska świeże, m. in. niżowa ląka rajgrasowa, łaka mieczykowo-mietlicowa i zbiorowiska zastępcze dla łąk świeżych. W wilgotniejszych miejscach obecne sa łaki ostrożeniowe i zespoły ziołorośli łakkowych, np. ziołorośla wiąówkowo-bodziszkowe. Wśród szuwarów można wyróżnić: szuwar trzcinowy, pałkowy, turzycowy, mozgowy, skrzypu bagiennego Equisetum fluviatile oraz wysoki i niski zespół szuwarów mannowych. Torfowiska niskoturzycowe reprezentowane sa przez młakę kozłkowo-turzycową. Ziołorośla $\mathrm{z}$ lepiężnikiem białym Petasites albus i różowym Petasites hybridus oraz śródleśna młaka ziołoroślowa $z$ kniecia błotna Caltha palustris i świerzabkiem orzęsionym Chaerophyllum hirsutum, to przykłady obecnych w Parku zbiorowisk ziołoroślowych. W miejscach pozostałości kultury łemkowskiej, jak np. cerkwiska i cmentarze, obecne sa zbiorowiska synantropijne, zwłaszcza zespół chabra miękkowłosego Centaurea mollis, którego siedlisko opisane zostało właśnie w MPN (CZADERNA 2009, MichaliK 2009). Obecne sa także relikty dawnych kultur ogrodowych (DuBIEL i współaut. 1998). Teren Magurskiego Parku Narodowego jest również dobrym miejscem do obserwowania wtórnej sukcesji roślin na terenie opuszczonych wsi połemkowskich (ZAJDEL 1997, FRACZEK i ZBOROWSKA 2010). Na różnorodność florystyczna składa się około 800 gatunków roślin naczyniowych, spośród których 56 to gatunki chronione (ZARZYCKA 2001, CZADERNA 2009, ZEMANEK 2009). Na uwage zasługuja mchy (MierZEŃSKA 2001, SteBel 2011), m.in. objęty ochrona ścisła bezlist okrywowy Buxbaumia viridis (KOZIK i VONČINA 2012).

Znajdujący się w godle Magurskiego Parku Narodowego orlik krzykliwy Clanga pomarina jest jednym $\mathrm{z}$ gatunków priorytetowych ochrony awifauny Parku (Ryc. 3). Ponadto, występuje tu szereg innych rzadkich i zagrożonych gatunków ptaków, m.in. 


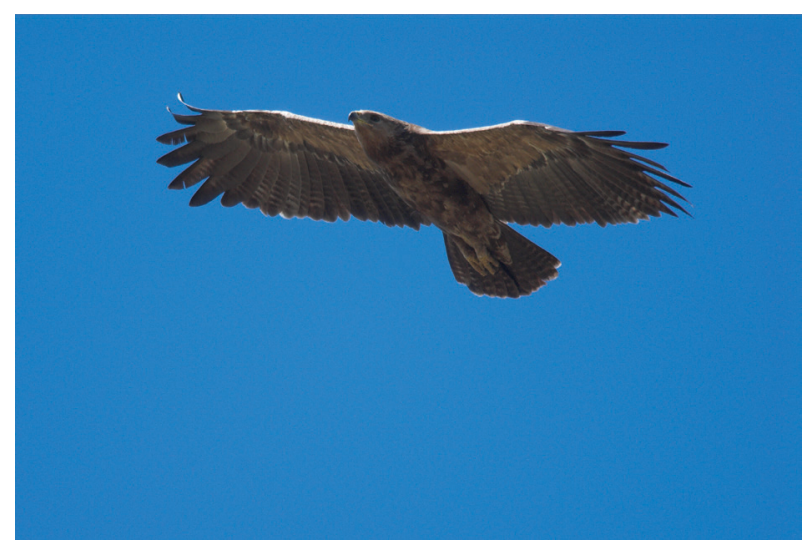

Ryc. 3. Orlik krzykliwy Clanga pomarina, gatunek będacy w godle MPN. Fot. D. Nowak.

orzeł przedni Aquila chrysaetos, puszczyk uralski Strix uralensis, sóweczka Glaucidium passerinum, włochatka Aegolius funereus, muchołówka mała Ficedula parva, muchołówka białoszyja Ficedula albicollis, jarzabek zwyczajny Tetrastes bonasia, a także dzięcioł trójpalczasty Picoides tridactylus i dzięcioł białogrzbiety Dendrocopos leucotos (STÓJ 1992, CZUCHNOWSKI i współaut. 2003, WILK i wpółaut. 2016). Teriofauna jest reprezentowana m.in. przez ssaki $z$ rzędu drapieżnych, jak niedźwiedź brunatny Ursus arctos, wilk szary Canis lupus, lis rudy Vulpes vulpes, ryś euroazjatycki Lynx lynx czy żbik europejski Felis silvestris. Licznie na terenie Parku wystęuja przedstawiciele jeleniowatych, jak jeleń szlachetny $\mathrm{Ce}$ rvus elaphus, sarna europejska Capreolus capreolus, a sporadycznie łoś euroazjatycki Alces alces (JAMROZY i współaut. 2000, GulA i współaut. 2002). Gatunkiem, który pojawił się stosunkowo niedawno na terenie MPN, jest bóbr europejski Castor fiber. Po reintrodukcji na początku lat 80. XX w., w 2007 r. liczebność tego gatunku oceniano już na ok. 60 osobników (JAMROZY i GÓRECKI 2009, ZBYRYT i ZBYRYT 2013). W skład parkowej herpetofauny wchodza najbardziej rozpowszechnione $\mathrm{w}$ Polsce gatunki gadów, czyli jaszczurka zwinka Lacerta agilis, jaszczurka żyworodna Zootoca vivipara i padalec kolchidzki Anguis colchica, a także zaskroniec zwyczajny Natrix natrix i żmija zygzakowata Vipera berus. Pojedyncze doniesienia mówią o obecności w otulinie Parku gniewosza plamistego Coronella austriaca, a w pobliżu granicy MPN, najrzadszego węża w Polsce, tj. węża Eskulapa Zamenis longissimus. Informacje te wymagaja jednak potwierdzenia. Na uwagę zasługuje obecność wszystkich krajowych płazów ogoniastych: salamandry plamistej Salamandra salamandra, traszki górskiej Ichthyosaura alpestris, traszki zwyczajnej Lissotriton vul-

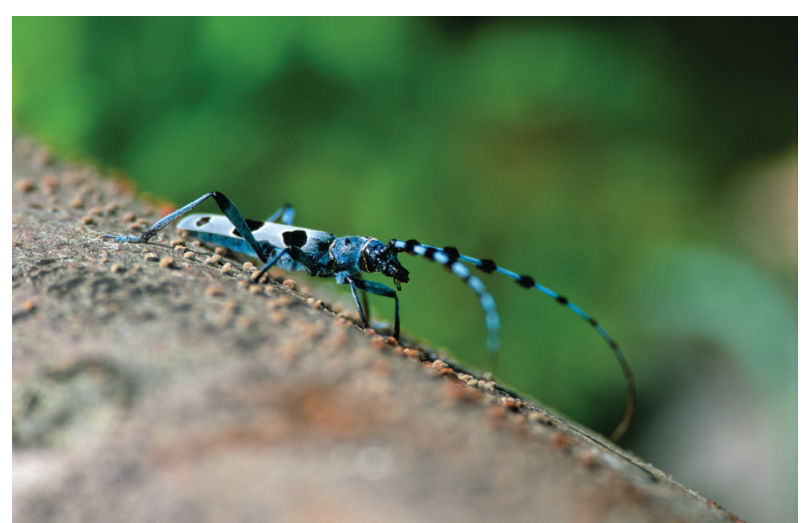

Ryc. 4. Nadobnica alpejska Rosalia alpina. Fot. D. Nowak.

garis, traszki karpackiej Lissotriton montandoni i traszki grzebieniastej Triturus cristatus. Na terenie MPN występuje 15 gatunków ryb. Najliczniejszym przedstawicielem tutejszej ichtiofauny są: szczebla potokowa Phoxinus phoxinus, kleń Squalius cephalus i brzanka Barbus meridionalis. Wśród bezkręgowców bogata jest fauna pędrusi i ryjkowców (PETRYSZAK 2003) oraz kózkowatych (KUBISZ i HILSZCZAŃSKI 1992), reprezentowanych tu np. przez licznie występująca nadobnicę alpejska Rosalia alpina (Ryc. 4) (Kosior i współaut. 1999). Obecni sa także liczni przedstawiciele pajęczaków (RozWAŁKA 2014), żukokształtnych (GóRZ 2012), motyli dziennych (ARTEMIUK i ŁOPUCKI 2011) i rodziny trzmielowatych (KosIOR i współaut. 2001). Nie sposób pominąć występującego na terenie Parku biegacza urozmaiconego Carabus variolosus oraz raków, np. szla-

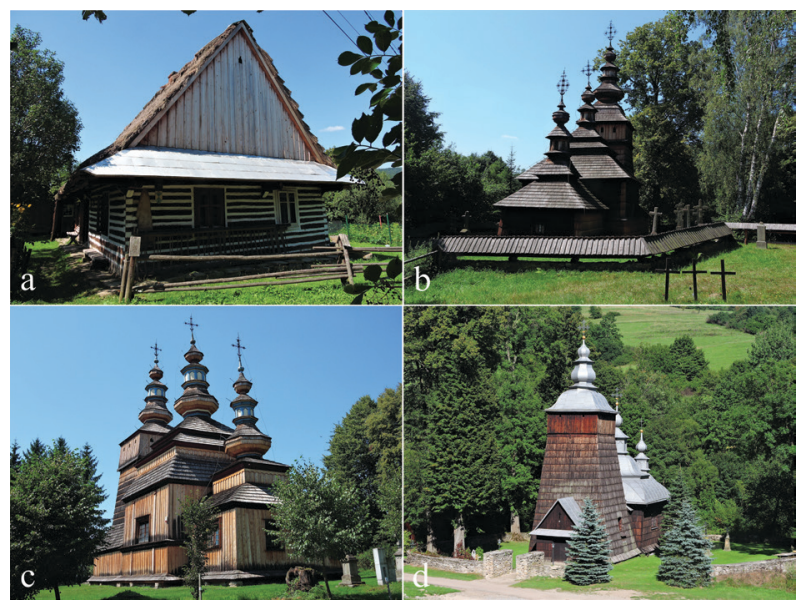

Ryc. 5. Architektoniczne pozostałości po kulturze łemkowskiej $z$ terenu MPN i otuliny Parku.

a - chyża łemkowska w Olchowcu, b - cerkiew grekokatolicka w Kotani, c - cerkiew grekokatolicka w Krempnej, d - cerkiew grekokatolicka w Chyrowej. Fot. J. Różański. 
chetnego Astacus astacus. Od pewnego czasu regularnie notuje się obecność modliszki zwyczajnej Mantis religiosa (PAWELEC 2003).

Należy również wspomnieć, iż miejscowości znajdujące się w granicach Parku i otuliny, bogate sa w historię zwiazana między innymi $z$ okresem I i II Wojny Światowej. Chaty zwane chyżami (Ryc. 5a) i liczne cerkwie (Ryc. 5b-d), przypominaja o niegdysiejszym, licznym zamieszkiwaniu tych rejonów przez Łemków.

\section{HISTORIA BADAŃ W MAGURSKIM PARKU NARODOWYM}

Przedstawione powyżej walory części Beskidu Niskiego, w której obecnie zlokalizowany jest Magurski Park Narodowy, od dawna wzbudzały zainteresowanie badaczy przyrody, historii i antropologii (zwłaszcza etnologii i etnografii). Niewatpliwie, dziedzinami o najstarszej tradycji badawczej w tym regionie sa nauki geologiczne, pedologiczne, hydrologiczne, klimatologiczne, a także zoologiczne i botaniczne, $z$ uwzględnieniem lichenologii i mykologii.

Historia badań nad geologicznymi uwarunkowaniami rzeźby terenu Beskidu Niskiego miała poczatek jeszcze w drugiej połowie XIX w. Wyznaczony został podział warstw, na których obecnie znajduje się jednostka magurska, a więc warstwy ropianieckie i magurskie (PAUL 1869). Kontynuowane przez Paula oraz innych naukowców badania doprowadzily do ustalenia zarysu litostratygrafii oraz zarysu tektonicznego jednostki magurskiej. Następnie, w rejonie Światkowej wyodrębniono łupki grybowskie (BOHM 1931, TEISSEYRE 1932), a w 1956 r. określono ich wiek na oligoceński (KozIKOwSKI 1956). Zebrane przed II wojna światowa dane zostały podsumowane w Regionalnej Geologii Polski (ŚWIDZIŃSKI 1953). W 1985 r. na przedpolu płaszczowiny magurskiej (okolice Osobnicy) wydzielona została płaszczowina jasielska (KosZARSKI 1985). Do ważniejszych odkryć należy także wyodrębnienie piaskowców z Mszanki (WARCHAEOWSKA-PAZDROWA 1930) oraz zaklasyfikowanie i wprowadzenie nazwy piaskowców cergowskich (TEISSEYRE 1932).

Podział i ogólna charakterystyka rzeźby terenu Beskidu Niskiego po raz pierwszy została opisana na poczatku XX w., $z$ podkreśleniem zależności ukształtowania terenu od struktury podłoża, co przekłada się na rusztowy typ gór i subsekwencje tamtejszych dolin (SMOLEŃSKI 1911). Następnie KLIMASZEWSKI (1935) dokonał podziału Beskidu Niskiego i wskazał na zależność rzeźby od odporności podłoża i ewolucji morfologicznej. Z kolei głównym przedmiotem zainteresowania STARKLA (1972) był opis zróżnicowania regionalnego rzeźby. Badacz ten podją następnie prace nad wpływem odporności podłoża i stylu tektoniki na formowanie się górskich grzbietów. Uzyskane $\mathrm{w}$ tych badaniach dane zostały uwzglednione $\mathrm{w}$ mapie geomorfologicznej Polski (STARKEL 1980). Warto także wspomnieć o odkryciach KOTARBY (1970) oraz LACHA (1971a, 1971b, 1975), dotyczacych uwarunkowań geologicznych oraz oddziaływania człowieka na morfologiczny charakter obszarów sąsiadujacych $z$ obecna lokalizacją MPN.

Badania pedologiczne, a więc zwiazane z gleboznawstwem, prowadzone były mniej więcej od połowy XX w. Początkowo dotyczyły one przede wszystkim analiz gleb uprawnych (np. KOMORNICKI i współaut. 1958, DOBRZAŃSKI 1963, UZIAK 1963). Następnie, prowadzono również badania $z$ zakresu funkcjonowania granicy rolno-leśnej (ADAMCZYK i współaut. 1973) i porowatości fliszowych skał macierzystych (MACIASZEK i WÓJCIK 1990). Po powstaniu MPN, pod kierownictwem prof. dr hab. Stefana Skiby zostały przeprowadzone kompleksowe badania gleboznawczo-kartograficzne, których efektem było opracowanie mapy glebowej Parku (SKIBA i współaut. 2000). Materiały te posłużyły do tworzenia Planu Ochrony MPN (SKIBA 1999). Szczegółowa charakterystyka gleb i ich mapa została opublikowana w monografii Przyroda Magurskiego Parku Narodowego (GÓRECKI i współaut. 2003).

Ogólne analizy hydrologiczne tego regionu prowadzono od lat 80. XX w. (np. DyNOWSKA 1971, PUNZET 1972). Badania $z$ tamtego okresu dotyczyły rzek Ropy (np. SoJA 1973) i Bystrzanki (SoJA 1981). Przeprowadzono również obserwacje wpływu przemian środowiska na obieg wody, a także pogłębienia koryt rzecznych (LACH 1975, SOJA 1988 , LACH i WyżGa 2001). Później przeanalizowano także warunki przemian opadu atmosferycznego w odpływ o różnym stopniu zagospodarowania, na przykładzie zlewni rzeki Jasiołki (ŻYCHOwski 2000). Ciekawe wyniki dotyczą także spływu powierzchniowego (SŁUPIK 1973). Istotne sa także dane związane $z$ różnymi parametrami hydrologicznymi, gromadzone przez działajaca od 1968 r. Stację Naukowa IGiPZ PAN w Szymbarku. W ostatnim dziesięcioleciu ciekawe badania dotyczyły czynników warunkujących występowanie drobnoustrojów w wodach, m.in. takie analizy wykonywano na Wisłoce i Ryjaku (Lasek 2011, 2013, 2014). Ogólne informacje o wodach powierzchniowych, podziemnych, ich jakości i zagrożeniach, można znaleźć w opracowaniach SOJA (2009) oraz LASEK i SiWKA (2012).

Badania klimatologiczne w Beskidzie Niskim rozpoczęto już $\mathrm{w}$ XIX $\mathrm{w}$. dzięki stacji 
meteorologicznej w Pilźnie, powstałej jeszcze w zaborze austriackim (HANIK 1972). Charakterystyczna dla Beskidu Niskiego, piętrowość klimatyczna opisana została w 1965 r. (HEss 1965). Badania te kontynuowano w latach kolejnych, efektem czego była dogłębna analiza poszczególnych elementów klimatu regionu (MichNA 1978, HEss i OLECKI 1984). W latach 50. XX w., zaczęto prowadzić ciagłe pomiary dotyczace klimatu (OBRĘBSKA-STARKLOWA 1993).

Historia badań botanicznych $z$ obszarów, na których obecnie znajduje się Magurski Park Narodowy, siega XIX w. (WoŁosZCZAK 1986). Liczne badania nad roślinami naczyniowymi miały jednak charakter ogólny, tylko w części dotycząc obszaru Parku (np. TACIK i współaut. 1957, GRODZIŃSKA 1968). Lepiej poznane zostały zbiorowiska nieleśne (DUBIEL i współaut. 1999). Na potrzeby Planu Ochrony MPN wykonano także prace inwentaryzacyjne roślin naczyniowych. Dane $z$ tych prac dostepne sa w bazie komputerowej Regionalny Atlas Roślin (Zając i współaut. 2000, dane nieopubl.). Obserwacje lichenologiczne na obszarach dzisiejszego MPN rozpoczęto w 1927 r. (MOTYKA 1927). Znacznie później opublikowano pracę szacujacą liczbę porostów w Beskidzie Niskim na 226 gatunków (OLECH 1974). W 2003 r. na bazie materiałów publikowanych wydano zestawienie, $z$ którego wynika, iż w Beskidzie Niskim jest 338 gatunków porostów. Zdecydowana ich większość występuje także w MPN (BIELCZYK 2003).

Pierwsze wzmianki o obserwacjach fauny bezkręgowców $z$ tej części rejonu Beskidu Niskiego pochodza $z$ drugiej połowy XIX w (NowICKI 1865). Bardziej zaawansowane badania rozpoczęły się po II Wojnie Światowej, a największe zasługi maja badajacy motyle Marian Chrostowski (CHROsTOWSKI 1964) i Jan Rafalski, który rozpoczą w tym rejonie badania nad fauna epigeiczna (RAFALSKI 1956, 1958, 1961). Okazyjnie pobierane próby fauny edaficznej w kolejnych latach przyniosły między innymi takie odkrycia, jak migracja Polistichus connexus (Coleoptera: Carabidae) oraz powrót do fauny Polskiej Oxythyrea funesta (Coleoptera: Carabidae) (SzWAŁKO 1989, WOJAS 1991, KUBISZ i współaut. 1991, KUBISZ i HILSZCZAŃSKI 1992, PETRYSZAK i współaut. 1993). Jeżeli chodzi o bezkręgowce wodne, to warto wymienić prace na temat chruścików (DZIEDZIELEWICZ 1919, 1920; TOMASZEWSKI 1965), pluskwiaków wodnych (WRÓBLEWSKI 1958), a także wypławków (GIEYSzTOR 1952). Były to jedne $z$ pierwszych publikacji o faunie wodnych bezkręgowców $z$ tego rejonu Polski. Czynnikiem determinującym wzmożone zainteresowanie fauna bezkręgowców MPN był projekt dwudziestoletniego Planu Ochrony Parku.

Ichtiofauna obecnego obszaru MPN przez długi czas była słabo poznana. Pierwsze informacje dotyczace ryb pojawiły się na poczatku lat 80. (RoLIK 1971), ale obszerniejsze dane zostały opracowane i opublikowane już za czasów istnienia MPN (WŁODEK i SKÓRA 1999). Kompleksowe badania nad ichtiofauna i jej zagrożeniami wykonano w Parku dopiero w XXI w. (KukUŁA 2002). Bardzo słabo poznanymi grupami omawianego rejonu sa płazy i gady. Pierwsze prace o herpetofaunie tych obszarów opublikowano pod koniec XX w (ŚwIERAD 1988, MicHALIK 1995). Dokładniejsze prace monitoringowe zaczęto prowadzić dopiero po powstaniu Parku (BABIK i RAFIŃSKI 2001). Awifauna Parku stała się obiektem dokładniejszych badań w latach 1984-1992. Projektowany wówczas obszar MPN objęto inwentaryzacją, która wykazała obecność 137 gatunków ptaków (STÓJ 1992). Inwentaryzacja obejmowała wówczas także Jaśliski Park Krajobrazowy (STóJ 1997). Badano również zasiedlenie obecnego obszaru Parku przez wybrane gatunki ptaków, np. bociana czarnego Ciconia nigra (STós 1991, 1995) i orła przedniego (STÓJ 2004, 2006). Prowadzone w latach 1997-2001, kompleksowe badania nad awifauna zostały wykorzystane do projektu Planu Ochrony Parku (WASILEWSKI i ZAJCHOWSKI 2000, PIKUNAS 2001, CZUCHNOWSKI i współaut. 2003). Podobnie jak w przypadku awifauny, teriofaune tych terenów wnikliwiej zaczęto badać dopiero po powstaniu Magurskiego Parku Narodowego. Wcześniejsze wzmianki o faunie ssaków tych obszarów, pojawiły się w literaturze jedynie w odniesieniu do diety sów (KULCZYCKI 1964), w danych HAITLINGERA i SzYSZKI (1977) oraz w Atlasie rozmieszczenia ssaków $w$ Polsce (PUCEK i RACZYŃSKI 1983). Po 1995 r. powstały licznie publikacje $z$ zakresu inwentaryzacji, ekologii czy wymogów siedliskowych i dynamiki populacyjnej ssaków (np. JAMROZY i TOMEK 1997, JAMROZY 2001, JAMROZY i GÓRECKI 2003). Opracowania te były także podstawa dla Planu Ochrony Fauny Parku (JAMROZY i współaut. 2000).

\section{BADANIA NA OBSZARZE MAGURSKIEGO PARKU NARODOWEGO W LICZBACH}

Powstanie Magurskiego Parku Narodowego bez watpienia było dodatkowym impulsem dla naukowców do prowadzenia badań w tym rejonie Beskidu Niskiego. Wskazuje na to między innymi rosnaca liczba wydawanych zgód na prowadzenie badań, liczba publikacji i przygotowanych w Parku prac 
Liczba próśb o zezwolenia, publikacji i prac dyplomowych w MPN z podzialem na lata

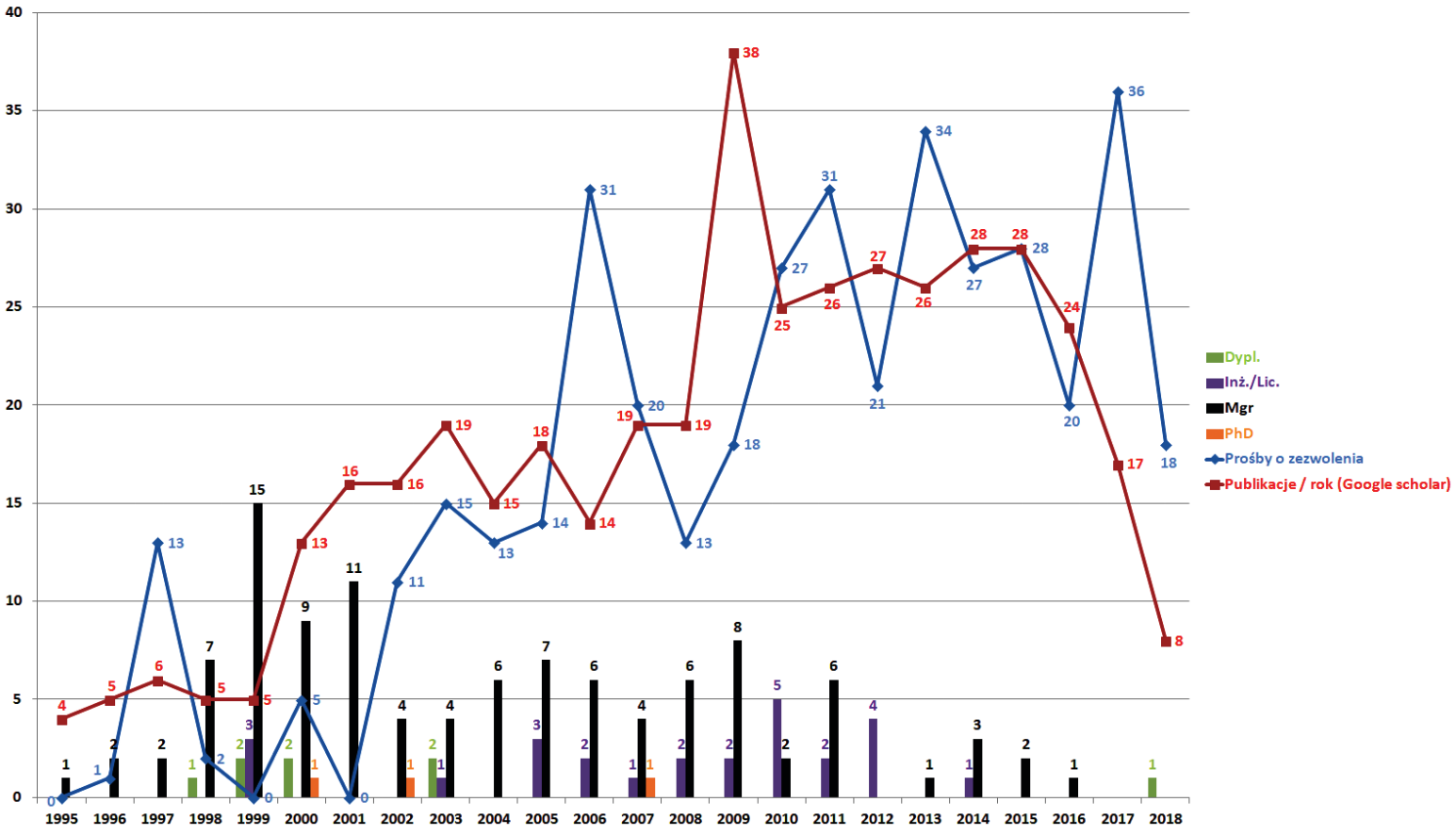

Ryc. 6. Różne formy badań realizowanych na terenie MPN w latach od 1995 do 2018.

dyplomowych (Ryc. 6). Dodatkowo, dzięki współpracy $z$ uczelniami, np. Uniwersytetem Rolniczym w Krakowie i Uniwersytetem Jagiellońskim, pracownicy naukowi i studenci wykonujacy badania lub praktyki na terenie MPN maja do dyspozycji terenowe stacje badawcze, m.in. w nieistniejacych wsiach Żydowskie i Ciechania oraz w pobliżu szczytu Baranie.

Rokiem, w którym na podstawie liczby wydanych zgód zaobserwowano wzmożone zainteresowanie prowadzeniem badań w MPN był 1997 r., a więc trzeci rok istnienia Parku (Ryc. 6). W latach 2001-2017, pomimo znaczącej zmienności między poszczególnymi latami, tendencja ta była wzrostowa (Ryc. 6). Rekordową liczbę wydanych zgód na badania, odnotowano w 2017 r., niewiele mniej w 2013 r. W 2018 r. nastapił nieoczekiwany, drastyczny spadek ich liczby (Ryc. 6).

Od chwili powstania MPN, co roku publikowano kilka artykułów naukowych, przynajmniej w części realizowanych na terenie Parku. Wyraźną tendencję wzrostowa zaobserwowano od 1999 r., a najwyższa liczbe publikacji odnotowano w 2009 r. Po 2015 r. stwierdzono jednak trend spadkowy (Ryc. 6). Dziedzinami naukowymi, w których publikowano najwięcej artykułów była zoologia, nauki środowiskowe i turystyka (Ryc. 7). $\mathrm{Na}$ dalszych miejscach pojawiały sie botanika, geologia i socjologia (Ryc. 7). Kilka artyku- łów dotyczyło edukacji przyrodniczej, leśnictwa, finansów i historii regionu. Odnotowano także pojedyncze publikacje zwiąane $z$ naukami prawnymi, etnologia, infrastruktura i rozwojem technologicznym (Ryc. 7).

Od chwili powołania Parku prowadzona jest dokładna ewidencja przygotowywanych tu prac dyplomowych. Przyszli doktorzy, magistrzy lub inżynierowie, proszeni byli także o przesłanie jednego egzemplarza pracy dyplomowej do biblioteki MPN, co ułatwia kolejnym piszącym nawiazanie do wyników poprzedników. Do końca 2018 r. na terenie Parku napisanych zostało 8 pozauniwersyteckich prac dyplomowych (głównie $z$ techników leśnych), 26 prac inżynierskich lub licencjackich, 106 prac magisterskich i 3 rozprawy doktorskie (Ryc. 6), a więc 143 prace dyplomowe. Najwięcej prac napisano w 1999 r. (2 dyplomowe, 3 inżynierskie/ licencjackie, 15 magisterskich). Także lata 2000 i 2001 były pod tym względem wyjatkowo płodne (Ryc. 6). W latach 2002-2011, liczba prac, ustabilizowała się na poziomie blisko 10/rok. Niestety od 2012 r. zaobserwowany jest wyraźny spadek liczby prac dyplomowych wykonywanych na terenie Parku (Ryc. 6). Być może jest to stan przejściowy, do zmiany którego, przyczyni się również niniejszy artykuł.

Należałoby w tym miejscu wspomnieć także o działalności edukacyjnej prowadzonej przez pracowników Magurskiego Parku $\mathrm{Na}-$ 


\section{Liczba publikacji w MPN z podzialem na dziedziny naukowe}

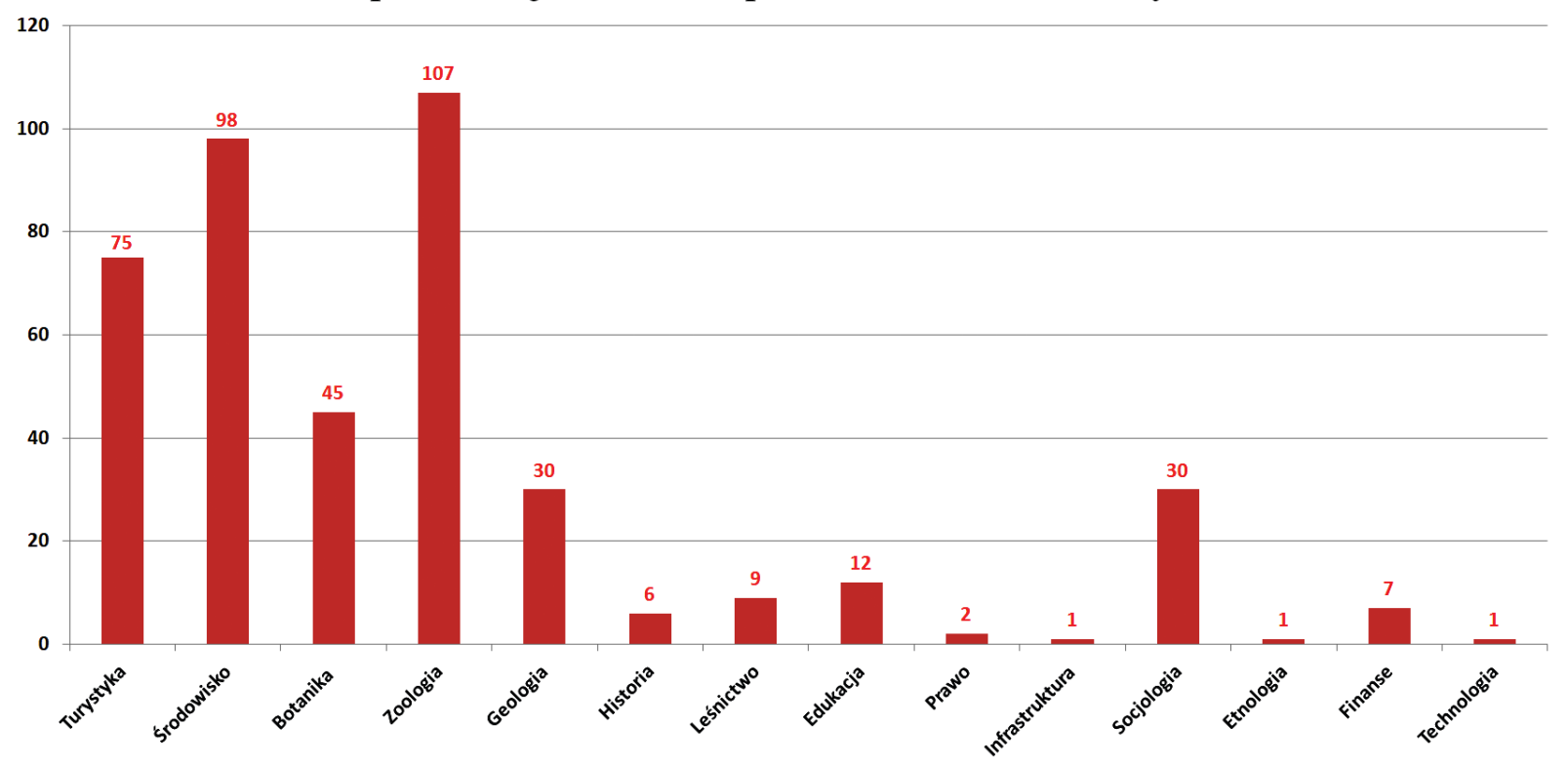

Ryc. 7. Wykres podsumowujacy liczbę publikacji z terenu MPN, z podziałem na dziedziny nauki.

rodowego. Jednym $z$ kluczowych wydarzeń było powstanie i udostępnienie w 2004 r. Ośrodka Edukacyjnego wraz z Muzeum, w sassiedztwie siedziby Parku, zlokalizowanej w miejscowości Krempna, w powiecie jasielskim. Pracownicy muzeum od poczatku istnienia ośrodka prowadzili działalność $z$ zakresu edukacji oraz ochrony i monitoringu przyrody. W 2009 r. wyodrębniono w muzeum trzy zespoły: ds. Udostępniania Parku, ds. Edukacji i ds. Ochrony Przyrody. Specjaliści $z$ poszczególnych zespołów realizuja liczne projekty edukacyjne oraz monitoringowo-badawcze. Przedmiotem jednego $z$ nich była identyfikacja szlaków migracyjnych dużych ssaków. Przeprowadzono wówczas także obserwacje przestrzeni żerowiskowej wykorzystywanej przez orlika krzykliwego w Beskidzie Niskim. W ramach projektu realizowanego w latach 2018-2019, zaplanowano przebudowę Ośrodka Edukacyjnego wraz $z$ Muzeum, czemu towarzyszyła zmiana nazwy na Ośrodek Edukacyjno-Muzealny im. Jana Szafrańskiego w Krempnej. Celem inwestycji jest rozszerzenie oraz uzupełnienie oferty wystaw i ekspozycji zwiazanych $z$ przyroda i dziedzictwem kulturowym obszaru Magurskiego Parku Narodowego. Ekspozycje te, w połaczeniu $z$ organizacją licznych warsztatów edukacyjnych dla młodzieży, mają szansę przyczynić się do zwiększenia zainteresowania realizacja badań na terenie Parku w przyszłości. Wiadomo bowiem, że edukacja jest podstawa rozwoju nauki.

Pomimo że Magurski Park Narodowy jest jednym $z$ najmłodszych parków narodowych w Polsce (czwarty od końca listy), już teraz można zaobserwować tendencję wzmożonego zainteresowania prowadzeniem badań naukowych w tej części Beskidu Niskiego. Świadczy to o istotnej roli parków narodowych nie tylko $z$ punktu widzenia ochrony przyrody, ale także stwarzania dogodnych warunków dla edukacji oraz prowadzenia badań w różnych dziedzinach nauki.

\section{ZASADY PROWADZENIA BADAŃ} NAUKOWYCH NA TERENIE MAGURSKIEGO PARKU NARODOWEGO

Aby prowadzić badania naukowe w Magurskim Parku Narodowym należy uzyskać zgodę dyrektora Parku, zgodnie $z$ art. 15 ust. 3 Ustawy o ochronie przyrody $z$ dnia 16 kwietnia 2004 r. W przypadku, gdy badania wymagaja odstępstw od zakazów dotyczacych czynności na terenie parku narodowego, zawartych w art. 15 i 52 ust. 1 Ustawy o ochronie przyrody, należy uzyskać zgodę Ministra Środowiska. Zakres i metodyka proponowanych tematow badawczych musza być zgodne $z$ wszystkimi obowiązującymi przepisami - Ustawa o ochronie przyrody, rozporzadzeniami o ochronie gatunkowej, a także $z$ odnośnymi punktami Rozporzadzenia Rady Ministrów o powołaniu MPN. Istotna jest także zgodność propozycji badawczych $z$ wytycznymi zawartymi w wieloletnim Planie Ochrony i $z$ sugerowanymi w nim priorytetami.

Ubiegać się o prowadzenie badań naukowych w Magurskim Parku Narodowym moga 
zarówno instytucje naukowe, jak i osoby prywatne, posiadające odpowiednie kompetencje $\mathrm{w}$ danym zakresie badawczym. Osoby, które nie sa samodzielnymi pracownikami naukowymi, powinny do projektu badań dołączyć opinię opiekuna naukowego (przynajmniej ze stopniem doktora habilitowanego) lub ewentualnie merytoryczne poręczenie ze strony instytucji naukowej, właściwej dla danej dyscypliny badawczej. Wpływajace do MPN propozycje badawcze przegląda i wstępnie przygotowuje do akceptacji Zespół ds. ochrony przyrody, a zatwierdza Dyrektor MPN. W przypadku projektów badawczych i monitoringowych znaczaco wpływajacych na przyrodę MPN, decyzja o ich akceptacji podejmowana jest na posiedzeniu Rady Parku. MPN informuje wykonawców o wszelkich zmianach mogacych mieć wpływ na przebieg badań. Wraz $\mathrm{z}$ zakończeniem projektu badawczego i opublikowaniem wyników, wykonawca powinien dostarczyć jeden egzemplarz opracowania lub jeden egzemplarz woluminu czasopisma nieprenumerowanego przez Park. W przypadku opracowań niepublikowanych np. prac dyplomowych, należy dostarczyć jeden oprawiony egzemplarz pracy, a także nieoprawiona kserokopię lub płytę $\mathrm{CD}$ w formacie uzgodnionym $\mathrm{z}$ pracownikiem merytorycznym MPN. Wszystkich wykonawców obowiązuje coroczne sporządzanie sprawozdania $z$ prowadzonych prac. Pragniemy zapewnić, iż Magurski Park Narodowy zawsze jest otwarty na propozycje projektów badawczych przez wszelkie jednostki naukowe, a także osoby prywatne.

\section{ZAKOŃCZENIE}

Dotychczas przeprowadzone na terenie Magurskiego Parku Narodowego badania wskazuja, iż obszar ten ma istotny wpływ na rozwój dziedzin wiedzy zwiazanych przede wszystkim $z$ naukami środowiskowymi. Wzrost zainteresowania naukowców ta częścią Beskidu Niskiego w okresie po powstaniu MPN, sugeruje niebagatelny wplyw istnienia parków narodowych na badawczy rozwój danego regionu. Nadal jednak istnieje wiele słabo poznanych dziedzin i tematów badawczych dotyczacych obecnego obszaru Parku. Do takich zagadnień można zaliczyć dokładna analizę niektórych grup bezkręgowców, np. ślimaków lądowych, skoczogonków czy dżdżownic, oraz kulturoznawcze i etnograficzne badania Łemkowszczyzny.

$$
\text { Streszczenie }
$$

Zasadniczym celem pracy jest zapoznanie czytelników z walorami przyrodniczymi i kulturowymi obszaru, na którym obecnie zlokalizowany jest Magurski Park Narodowy. Drugim celem było wykazanie wkładu Parku w rozwój różnych dziedzin nauki i rosnacego zainteresowa- nia badaczy tym rejonem. Przedstawiamy także zasady udostępniania Parku dla nauki i zachęcamy do realizowania prac dyplomowych oraz projektów badawczych na terenie Magurskiego Parku Narodowego.

\section{LITERATURA}

ADAMCZYK B., MACIASZEK W., JANUSZEK K., 1973. Gleby gromady Szymbark $i$ ich wartość użytkowa. Dokumentacja Geograficzna IG PAN 1, 15-72.

ARTEMIUK A., ŁOPUCKI R., 2011. Fauna motyli dziennych (Lepidoptera: Rhopalocera) zbiorowisk łakowych Obwodu Ochronnego Huta Krempska $w$ Magurskim Parku Narodowym. Roczniki Bieszczadzkie 19, 247-259.

BABIK W., RAFIŃSKI J., 2001. Amphibian breeding site characteristics in the Western Carpathians, Poland. Herpetol. J. 11, 41-51.

BIELCZYK U., 2003. The lichens and allied fungi of the Polish Carpathians - an annotated checklist. W. Szafer Institute of Botany, Polish Academy of Sciences, Kraków.

BoHм B., 1931. Sprawozdanie $z$ badań geologicznych wykonanych w r. 1930 w okolicy Zmigrodu. Posiedzenia Naukowe Państwowego Instytutu Geologii 30.

Chrostowski M., 1964. Nowe podgatunki Parnassius mnemosyne L. (Lepidoptera, Papilionidae) $z$ Karpat $i$ ich przedgórza. Polskie Pismo Entomologiczne 34, 189-196.

CZUCHNOWSKI R., WASILEWSKI J., BONCZAR Z., KULCZYCKI A., STÓJ M., PIKUNAS K., 2003. Awifauna legowa Magurskiego Parku Narodowego. Parki Narodowe i Rezerwaty Przyrody 22. 449-471.

CZADERNA A., 2009. Walory Magurskiego Parku Narodowego $i$ ich ochrona. Roczniki Bieszczadzkie 17, 147-163.

DoBRZAŃSKI B., 1963. Przydatność użytkowa gleb Karpat Fliszowych. Roczniki Gleboznawcze $13,26-46$.

DUBIEL E., GAWROŃSKI S., STACHURSKA A., 1998. Relikty dawnych kultur ogrodowych w Magurskim Parku Narodowym. Fragmenta Floristica et Geobotanica Polonica 5, 101-108.

Dubiel E., STACHURSKA A., GAWROŃSKI S., 1999. Nieleśne zbiorowiska roślinne Magurskiego Parku Narodowego (Beskid Niski). Prace Botaniczne 33, 1-60.

DYNOWSKA I., 1971. Typy reżimów rzecznych $w$ Polsce. Zeszyty Naukowe UJ, Prace Geograficzne 28, 1-147.

DZIEDZIELEWICZ J., 1919. Owady siatkoskrzydle ziem Polski. Rozprawy i wiadomości $z \mathrm{Mu}-$ zeum imienia Dzieduszyckich 3, 105-168.

DZIEDZIELEWICZ J., 1920. Owady siatkoskrzydle ziem Polski. Rozprawy i wiadomości $z \mathrm{Mu}-$ zeum imienia Dzieduszyckich 4, 1-72.

FRACZEK M., ZBOROWSKA M., 2010. Wtórna sukcesja leśna na terenie dawnej wsi Świerzowa Ruska w Magurskim Parku Narodowym. Roczniki Bieszczadzkie 18, 112-128.

GIEYSZTOR M., 1952. Wirki. Popularne monografie zoologiczne. PWN, Warszawa.

Górecki A., KrZemień K., SkiBA S., ZemaneK B., 2003. Przyroda Magurskiego Parku Narodowego. Magurski Park Narodowy, Uniwersytet Jagielloński, Krempna, Kraków.

GÓRZ A., 2012. Wstepne wyniki badań nad koprofagicznymi żukami Coleoptera: Scarabaeoidea $w$ Magurskim Parku Narodowym $i w$ jego otulinie. Roczniki Bieszczadzkie 20, 214-219. 
GRODZIŃSKA K., 1968. Rośliny naczyniowe Pasma Bukowicy (Beskid Niski). Fragmenta Floristica et Geobotanica 14, 3-82.

Gula R., KRZAKIEWICZ H., NIEMCZYK J., LUKACIEJEWSKi G., PASZKIEWICZ R., SZKuTNIK M., KaliNOWSKI W., WASZKIEWICZ A., 2002. Inwentaryzacja wilków $i$ rysi $w$ południowo-wschodniej Polsce. Roczniki Bieszczadzkie 10, 373-389.

HANIK J., 1972. Dzieje meteorologii $i$ obserwacji meteorologicznych $w$ Galicji od XVIII do XX wieku. Monografie $\mathrm{z}$ dziejôw nauki i techniki $75,1-214$.

HAITLINGER R., SZYSZKA K. 1977. Drobne ssaki Gorców, Beskidu Wyspowego, Pasma Radziejowej i niektórych obszarów sasiednich. Przegląd Zoologiczny 21, 155-170.

Hess M., 1965. Piętra klimatyczne w Polskich Karpatach Zachodnich. Zeszyty Naukowe UJ, Prace Geograficzne 11, 1-258.

HESS M., OLECKI Z., 1984. Zróżnicowanie całkowitego promieniowania słonecznego na obszarze Karpat. Zeszyty Naukowe UJ, Prace Geograficzne 58, 49-63.

JAMROZY G., TOMEK A., 1997. Wystepowanie dużych ssaków $w$ Magurskim Parku Narodowym. Parki Narodowe i Rezerwaty Przyrody $16,79-89$

JAMrozy G., Górecki A., 2003. Ssaki. [W:] Przyroda Magurskiego Parku Narodowego. GÓRECKI A., KRZEMień K., SkiBA S., ZemaneK B. (red.). Magurski Park Narodowy, Uniwersytet Jagielloński, Krempna, Kraków, 137-145.

JAMROZY G., GÓRECKI A., 2009. Ssaki. [W:] Magurski Park Narodowy - Monografia Przyrodnicza. GóRECKI A., ZEMANeK B. (red.). Oficyna Wydawnicza Text, Kraków, 9-14.

JAMROZY G., GóRECKI A., JABEOŃSKA I., TOMEK A., 2000. Ssaki Magurskiego Parku Narodowego. Parki Narodowe i Rezerwaty Przyrody 19, 127-141.

KLIMASZEWSKI M., 1935. Z fizjografii Beskidu Niskiego. Wierchy $13,89-93$.

KOMORNICKI T., ADAMCZYK B., POLAK S., 1958. Gleby gromady Mochnaczka Niżna k. Krynicy. Roczniki Nauk Rolniczych 72, 1015-1041.

KOSIOR A., MichaliK S., WiTKOWSKI Z., 1999. Nadobnica alpejska Rosalia alpina (Cerambycidae, Coleoptera) w Magurskim Parku Narodowym na tle jej rozmieszczenia $w$ Polsce. Chrońmy Przyrodę Ojczysta 55, 79-84.

Kosior A., KRÓL W., PeONKA P., 2001. Trzmielowate (Bombini, Apoidea) Magurskiego Parku Narodowego $i$ jego otuliny. Parki Narodowe i Rezerwaty Przyrody 20, 29-54.

KOSZARSKI L., 1985. Geology of the Middle Carpathians and the Carpathian Foredeep. Guide to exc. 3. Carpato-Balkan Geological Ass. XIII Congr. Cracow, Poland, 245.

KOTARBA A., 1970. Chrakterystyka rzeźby okolic Szymbarku. Dokumentacja Geograficzna 3, $7-24$.

KOZIK J., VončINA G., 2012. Odkrycie bezlistu okrywowego Buxbaumia viridis (Bryopsida, Buxbaumiacae) $w$ Beskidzie Niskim (Karpaty Zachodnie). Roczniki Bieszczadzkie 20, 378383.

KozIKOWsKI H., 1956. Jednostka Ropy-Pisarzowej, nowa jednostka tektoniczna polskich Karpat fliszowych. Biuletyn Państwowego Instytutu Geologicznego 110, 93-129.

KUBISZ D., HILSZCZAŃSKI J., 1992. Fauna kózkowatych (Coleoptera, Cerambycidae) Beskidu Niskiego. Wiadomości Entomologiczne 11, 2.

Kubisz D., STOLzMANN P., GRABOWSKI G., 1991. Owady kambio- $i$ ksylofagiczne rezerwatu „Modrzyna” na przełęcyy Dukielskiej (Beskid
Niski). Parki Narodowe i Rezerwaty Przyrody 10, 93-101.

KuKUŁA K., 2002. Threats to the ichthyofauna of the Magurski National Park and its protective zone. Arch. Pol. Fisher. 10, 97-108.

KULCZYCKI A., 1964. Badania nad składem pokarmu sów $z$ Beskidu Niskiego. Acta Zoologica Cracoviensia 9, 529-559.

LACH J., 1971a. Geneza form skalnych pasma Magury Watkowskiej. Sprawozdania z Posiedzenia Komisji Nauk, Oddz. Kraków, PAN 14, 211-212.

LACH J., 1971b. Ewolucja $i$ typologia krajobrazu Beskidu Niskiego $z$ uwzglednieniem gospodarczej działalności człowieka. Prace Monograficzne WSP Kraków 16, 5-72.

LACH J., 1975. Ewolucja stosunków wodnych wywołana gospodarcza działalnościa człowieka $w$ dorzeczu Ropy. Zeszyty Problemowe Postępów Nauk Rolniczych 162, 365-369.

LACH J., WYŻGA B., 2001. Zmiany geometrii $i$ przepływu górnej Wisłoki po zwiększeniu się lesistości zlewni. Czasopismo Geograficzne 72, 329-355.

LASEK J., 2011, Changes in microbial concentrations during summer and winter extreme runoff events in a catchment featuring mixed land use - pilot study. Geophys. Res. Abstr. 13, EGU2011-12943.

LACH J., 2013. Factors affecting the concentration of $E$. coli in the Upper Wisloka drainage basin (The Carpathians, Poland). Fall Meeting, AGU, San Francisco, California, 9-13 Dec. 2013.

LACH J., 2014, Seasonal changes in microbial concentrations in two catchments featuring mixedland use. IGU Regional Conference, Kraków, Poland, 18-22 Aug. 2014, 1282.

LASEK J., SIWEK J., 2012. Magurski Park Narodowy. [W:] Wody $w$ parkach narodowych Polski. BOGDANOWICZ R., JOKIEL P., POCIASK-KARTECZKA J. (red.). IGiGP UJ, KH PTG, Kraków, $137-147$.

MACIASZEK W., WÓJCIK A., 1990. Właściwości fizyczne wybranych szkieletowych gleb

leśnych wytworzonych ze skat warstw podmagurskich $w$ Beskidzie Niskim. Roczniki Gleboznawcze 41, 23-33.

MichaliK S., 1995. Magurski Park Narodowy. Chrońmy Przyrode Ojczystą 51, 19-37.

Michalik S., 2009. Zbiorowiska roślinne. [W:] Magurski Park Narodowy - Monografia Przyrodnicza. GóRECKI A., ZEMANEK B. (red.). Oficyna Wydawnicza Text, Kraków, 96-120.

MichNA E., 1978. Zróżnicowanie klimatyczne obszaru płd.-zach. Polski $w$ świetle temperatur powietrza. [W:] Studia nad typologia $i$ ocena środowiska geogr. Karpat $i$ Kotliny Sandomierskiej. STARKEL L. (red.). Prace Geograficzne IGiPZ PAN 125, 63-79.

MIERZEŃSKA M., 2001. Materiały do geograficznego rozmieszczenia watrobowców (Hepaticae) w Polsce. 1. Watrobowce Magurskiego Parku Narodowego. Fragmenta Floristica et Geobotanica Polonica 8, 257-261.

MотүкA J., 1927. Studia nad nadrzewnymi zespołami porostów $w$ lasach okolic Grybowa jako przyczynek do znajomości typów lasów w Beskidach. Sylwan 45, 1-14, 73-84, 141-148.

NowICKI M., 1865. Motyle Galicyi. Drukarnia Instytutu Stauropigiañskiego, Lwów.

OBREBSKA-STARKLOWA B., 1993. O badaniach fitofenologicznych $w$ Galicji $w$ XIX wieku na tle rozwoju fenologii $w$ Europie). Przegląd Geograficzny 3-4, 289-296.

Olech M., 1974. Materiały do flory porostów Beskidu Niskiego. Zeszyty Naukowe Uniwersyte- 
tu Jagiellońskiego. Prace Botaniczne 2,181200.

PAUL C. M., 1869. Die geologishen Verhaltnisse des nordlichen Saroser und Zempliner Comitates. Jahrbuch der Kaiserlich Königlichen Geologischen Reichsanstalt 18-19, 241-280.

PAWELEC J., 2003. Inwazja modliszek $w$ Magurskim Parku Narodowym. Parki Narodowe 4, $1-2$.

Petryszak B. 2003. Pedrusie i ryjkowce. [W:] Przyroda Magurskiego Parku Narodowego. GóRECKI A., KRZEMIEŃ K. (red.). Krempna, MPN - Kraków UJ, 101-112.

Petryszak B., Wróbel S., Czekaj A., Skalski T., 1993. Rujkowce (Coleoptera, Curculionidae) Beskidu Niskiego. Zeszyty Naukowe UJ, Prace Zoologiczne 38, 29-59.

PIKUNAS K., 2001. Distribution and abundance of the Common Buzzard (Butteo butteo) in Magura National Park (the Western Carpathians, Poland). Buteo 12, 199-126.

PUCEK Z., RACZYŃSKI J., 1983. Atlas rozmieszczenia ssaków $w$ Polsce. PWN, Warszawa.

PUNZET J., 1972. Tendencje zmian przebiegu wielkich wód $w$ dorzeczu górnej Wisły. Wiadomości Służby Hydrologiczno-Meteorologicznej 3-4, 29-40.

RAFALSKI J., 1956. Opis Siro carpaticus sp.n. wraz $z$ uwagami o morfologii $i$ systematyce Cyphophthalami (Opiliones). Sprawozdania Poznańskie T.P.N., 49-52

RAFALSKI J., 1958. Description of Siro carpaticus sp.n. with remarks on morphology and systematics if Cyphophthalami (Opiliones). Acta Zoologica Carcoviensia 2: 521-556.

RAFALSKI K., 1961. Prodromus faunae Opilionum Poloniae. Prace Komisji Biologicznej, Poznańskie Towarzystwo Przyjaciół Nauk 25, 325372 .

RolIK H., 1971. Studia nad gatunkiem rodzaju Barbus (Cuveir, 1817), z dorzecza Sanu $i$ Wisłoki (Pisces, Cyprinidae). Annales Zoologici 28, 257-330.

RozWAEKA R., 2014. Pajaki Araneae Magurskiego Parku Narodowego. Roczniki Bieszczadzkie 22, 351-370.

SkIBA S., 1999. Ochrona przyrody nieożywionej $i$ gleb. Plan Ochrony Magurskiego Parku Narodowego, 198.

SKIBA S., DREWNIK M., 2000. Pokrywa glebowa Magurskiego Parku Narodowego (Karpaty Beskid Niski). Roczniki Bieszczadzkie 9, 183 195.

SKIBA S., DREWNIK M., KACPRZAK A., KoŁODZIEJCZYK M., SZMUC R., 2000. Soil maps of Moun tain National Parks in Poland. Proceedings of International Symposium "Comparison of Polish and German Soil Classification Systems of Soil Cartography of Mountain and Sub-mountain Areas", Wrocław, 93-101.

SŁUPIK J., 1973. Zróżnicowanie spływu powierzchniowego na fliszowych stokach górskich. Dokumentacja Geograficzna 2, 1-118.

SMOLEŃSKI J., 1911. Z morfogenezy Beskidu Niskiego. Ksiega Pam. IX Zjazdu Lekarzy i Przyrodników Polskich, Kraków, 232-234.

SoJA R., 1973. Stosunki termiczne wody $w$ dorzeczu Ropy $w$ okresie maksymalnych temperatur powietrza. Przeglad Geograficzny 45, 587-598.

SoJA R., 1981. Analiza odptywu $z$ fliszowych zlewni Bystrzanki i Ropy (Beskid Niski). Dokumentacja Geograficzna 2, 1-91.

SoJA R., 1988. Zmiana odpływu w zlewni Wisłoki pod wpływem działalności człowieka. [W:] Antropogeniczne uwarunkowania zmian odpływu i reżimu rzek Polski. DyNOWSKA I. (red.). Dokumentacja Geograficzna 4, 9-22.

STARKEL L., 1980. Przegladowa mapa geomorfologiczna Polski 1: 500000 (oprac. zespołowe). IGiPZPAN, Warszawa.

STEBEL A., 2011. Kilka nowych gatunków mchów $z$ Magurskiego Parku Narodowego (Beskid Niski, Karpaty Zachodnie). Roczniki Bieszczadzkie 19, 141-147.

STóJ M., 1991. Występowanie i biologia orlika krzykliwego Aquila pomarina w Beskidzie Niskim. Chrońmy Przyrode Ojczysta 47, 28-35.

STóJ M., 1992. Ptaki projektowanego Magurskiego Parku Narodowego w Beskidzie Niskim. Chrońmy Przyrode Ojczysta 48, 12-21.

STós M., 1995. Ekologia rozrodu bociana czarnego Ciconia nigra $w$ Beskidzie Niskim $i$ okolicach Jasła. Chrońmy Przyrode Ojczysta 51, 29-39.

Stós M., 1997. Awifauna Jaśliskiego Parku Krajobrazowego $w$ Beskidzie Niskim. Chrońmy Przyrode Ojczysta 53, 45-58.

STóJ M., 2004. Orły przednie zagnieździły się $w$ Magurskim Parku Narodowym. Przyroda Polska 2,19.

STÓJ M., 2006. Orzeł przedni Aquila chrysaetos $w$ polskiej czesści Karpat w latach 1997-2005. Roczniki Bieszczadzkie 14, 155-166.

ŚWIERAD J., 1988. Płazy Karpat polskich w ujęciu wertykalnym. Instytut Kształcenia Nauczycieli, Katowice.

ŚwIDZIŃSKI H., 1953. Karpaty fliszowe miedzy Du najcem a Sanem.[W:] Regionalna Geologia Polski. t.1, Karpaty, z. 2, Tektonika. KSIĄŻKIEWICZ M. (red.). Polskie Towarzystwo Geologiczne, Kraków, 362-422.

SZAFRAŃSKI J. 2009. Historia $i$ dzień dzisiejszy Magurskiego Parku Narodowego. [W:] Magurski Park Narodowy - Monografia Przyrodnicza. GóRECKI A., ZEMANEK B. (red.). Oficyna Wydawnicza Text, Kraków, 9-14.

SzWAEKO P., 1989. Wystepowanie Oxythyrea funesta (Poda, 1761) (Coleoptera, Carabidae) $w$ Polsce. Przeglad Zoologiczny 33, 83-87.

TACIK T., ZAJACOWNA M, ZARZYCKI K., 1957. Z zagadnień geobotanicznych Beskidu Niskiego. Acta Societatis Botanicorum Poloniae 26, 17 43.

Tomaszewski C., 1965. Chruściki Trichoptera. Katalog Fauny Polski, XXVIII, Instytut Zoologiczny PAN, Warszawa.

TEISSEYRE H., 1932. Zarys budowy geologicznej Karpat Dukielskich. Sprawozdanie Państwowego Instytutu Geologicznego 7, 319-348.

UZIAK S., 1963. Geneza i klasyfikacja gleb górskich $w$ Karpatach Fliszowych. Roczniki Gleboznawcze 13, 56-71.

WARCHALOWSKA-PAZDROWA O., 1930. Budowa geologiczna okolic Dukli i Żmigrodu. Kosmos 54, 917-928.

WASILEWSKI J., ZAJCHOWSKI K., 2000. Występowanie oraz liczebność puszczyka Cinclus

cinclus i pliszki górskiej Motacilla cinerea na wybranych obszarach Polski południowo-wschodniej. Roczniki Bieszczadzkie 9, 157-168.

Wilk T., BOBReK R., PęPKOWSKA-KRÓL A., NEUBAUER G., KOSICKI J. Z., 2016. Ptaki polskich Karpat - stan, zagrożenia, ochrona. OTOP, Marki.

WŁODEK J. M., SKÓRA S., 1999. Badania ichtiofaunistyczne $w$ rzece $i$ dorzeczu Wisłoki $w$ la tach 1994-1995. Roczniki Naukowe PWN 12, 29-60.

WOJAS T., 1991. Nowe stanowiska rzadkich gatunków chrzaszczy $z$ rodziny biegaczowatych (Coleoptera, Carabidae) w Polsce. Wiadomości Entomologiczne 11, 185. 
WoŁOSZCZAK E., 1986. Z granicy flory zachodnio$i$ wschodnio-karpackiej. Sprawozdanie Komisji Fizjograficznej 31, 119-159.

WRÓBLEWSKI A., 1958. The Polish species of the genus Micronecta Krik (Heteroptera, Corixidae). Annales Zoologici 17, 247-382.

ZAJDEL G., 1997. Wsteppne wyniki badań nad wtórna sukcesja roślinności na terenie dawnej wsi Ciechania $w$ Magurskim Parku Narodowym. Roczniki Bieszczadzkie 6, 139-146.

ZARZYCKA M., 2001. Rośliny naczyniowe górnego biegu Wisłoki (Beskid Niski). Fragmenta Floristica et Geobotanica 8, 43-62.

ZBYRYT M., ZBYRYT A., 2013. Rekolonizacja Magurskiego Parku Narodowego przez bobra europej- skiego Castor fiber - 27 lat po reintrodukcji. Parki Narodowe i Rezerwaty Przyrody 32, 7988.

ZEMANEK B., 2009. Rośliny $i$ grzyby wielkoowocnikowe. [W:] Magurski Park Narodowy - Monografia Przyrodnicza. GÓRECKI A., ZEMANEK B. (red.). Oficyna Wydawnicza Text, Kraków, 9-14.

ŻYCHOWSKI J., 2000. Przyczyny różnej transformacji opadów $w$ odpływy $w$ dwóch zlewniach Beskidu Niskiego. [W:] Działalność człowieka $i$ jego środowisko. ZıoŁo Z. (red.). Wydawnictwo Naukowe Akademii Pedagogicznej w Krakowie, 93-120.

KOSMOS Vol. 68, 4, 621-631, 2019

Józef Różański, Damian NowaK, JarostaW SOCHACKI, KonRad KRASOŃ

Team for the Nature Conservation, Magurski National Park, Krempna 59, 38-232 Krempna,

E-mail: jrozanski@magurskipn.pl, jozekr1@poczta.onet.pl

MAGURSKI NATIONAL PARK - MEANING FOR SCIENCE

Summary

The main aim of the presented review is to introduce the readers to the natural and cultural values of the area, where nowadays the Magurski National Park is located. The second goal is to demonstrate the importance of the Park for the development of many fields of science and the growing interest of the researchers in this region. We also wish to introduce the readers to the principles for sharing the Magurski National Park for science, as well as invite scientists to conduct their researches in the Park e.g. for diploma thesis or scientific project.

Key words: Magurski National Park, nature, nature conservation, Park history, science in MNP 